
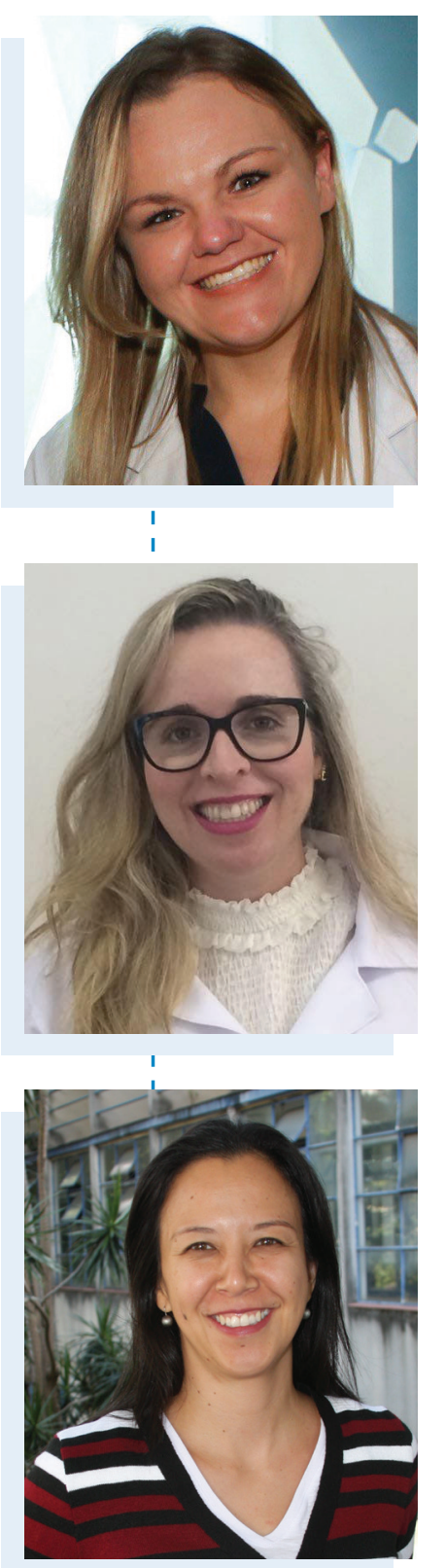

I

I

1

I

I

I

I

I

I

I

I

\title{
Medical Device-Related Pressure Injury in health care professionals in times of pandemic
}

\author{
Lesão por pressão relacionada a dispositivo médico nos \\ profissionais de saúde em época de pandemia
}

\section{Lesión por presión relacionada a un dispositivo médico en los profesionales de la salud en época de pandemia}

Aline de Oliveira Ramalho ${ }^{1,3,{ }^{*}, \text { Paula de Souza Silva Freitas }}{ }^{2}$, Paula Cristina Nogueira ${ }^{3}$

\section{ORCID IDs}

Ramalho AO (iD https://orcid.org/0000-0001-6065-5488 Freitas PSS (D) https://orcid.org/0000-0001-9066-3286 Nogueira PC (D) https://orcid.org/0000-0001-5200-1281

\section{HOW TO CITE}

Ramalho AO; Freitas PSS; Nogueira PC. Medical Device-Related Pressure Injury in health care professionals in times of pandemic. ESTIMA, Braz. J. Enterostomal Ther., 18: e0120; 2020. https://doi.org/10.30886/estima.v18.867_IN

Facing the number of cases of coronavirus infection (COVID-19), the World Health Organization $(\mathrm{WHO})$ has declared that the disease, present in several countries and continents, is a pandemic of global alert and mobilization ${ }^{1}$.

In Brazil, the pandemic arrived at the end of February 2020 and has been causing alarm due to the increase in the number of contaminated people related to the high capacity of transmission of the disease. In affected patients, the virus can cause from simple symptoms, which can be treated at home, to hospital admissions, assistance in intensive care units and can even lead to death'2.

In the midst of this pandemic, the professionals who assist patients with suspected or confirmed COVID-19 infection constitute a population at high risk of contagion. In this way, preventive measures such as adequate hand hygiene and the use of personal protective equipment (PPE) have been reinforced.

Among PPEs, N95 type and similar respiratory protection masks should be used to perform procedures that generate aerosols, such as: intubation, noninvasive ventilation, aspiration and other care. In addition, the Society of Intensive Care Medicine recommends the constant use of this protection in intensive care environments that treat patients with confirmation and/or suspicion of COVID-193.

The WHO recognizes the need for the use of a respiratory protection mask, but draws attention to the fact that it should not be used for more than $4 \mathrm{~h}$ in a row, due to the discomfort 
resulting from its use. However, something has been drawing the attention of nurses, especially enterostomal therapists, which are the Medical Device-Related Pressure Injuries ${ }^{4,5}$ caused by the use of N-95 mask. We have often seen in social media ${ }^{6}$ the dissemination of photos (Figs. 1 and 2) of health professionals with skin lesions in the area of application of this $\mathrm{PPE}^{7}$.
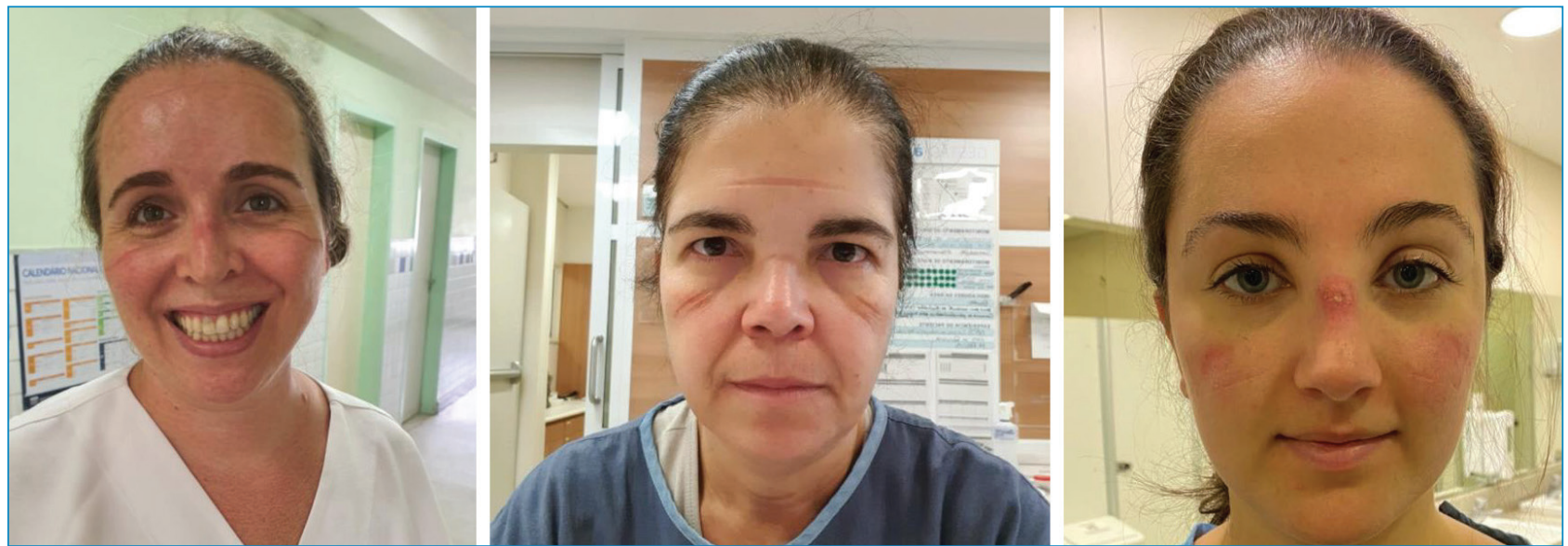

Figure 1. Brazilian professionals with pressure injuries related to mask use. Images published with permission.
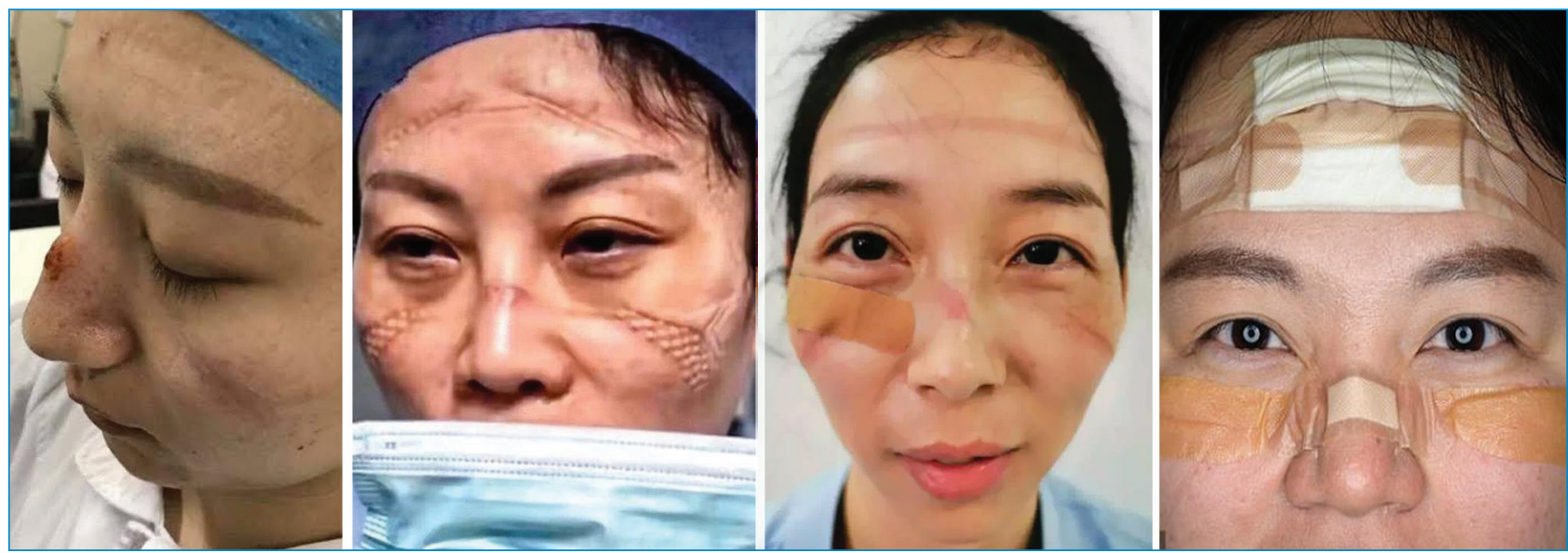

Figure 2. Images of Chinese healthcare workers with pressure injuries caused by PPE. ${ }^{6}$

Medical Device-Related Pressure Injury 4,5 has been gaining prominence in national and international research, especially because we know that the devices used in health care are often indispensable, making it necessary to implement preventive measures or preventive recommendations to preserve the integrity of the skin in the area exposed to risk..

However, until now, the preventive recommendations have been directed to the patients under our care, although, in face of the current demands, it is fundamental to turn the attention also to the maintenance of the integrity of the professional's skin, since the occurrence of the lesion can cause impacts on the care, quality of life and self-esteem, as well as presenting itself as an open door for infections.

With this in mind, some recommendations that are generally directed and carried out for the care of patients can also be applied to health professionals wearing breathing masks and other PPEs, in order to contribute to the maintenance of intact $\operatorname{skin}^{8,9}$ :

- Clean the skin with liquid soap, preferably with a $\mathrm{pH}$ compatible with the skin (slightly acidified) and moisturize the skin with a cosmetic product (moisturizing cream) without the presence of lipids;

- Apply a prophylactic coating as an interface between the skin and the mask attachment area (when the mask is used for a long time, especially in the zygomatic region and nasal bone), such as: thin polyurethane foam, silicone, transparent film or extra thin hydrocolloid plates; 
- Schedule minutes of pressure relief, with the possibility of removing the mask every $2 \mathrm{~h}$;

- Inspect the skin frequently and watch for signs of pain, discomfort, hyperemia and injury;

- Avoid placing the mask and other PPEs on areas of skin lesions, eczema or hyperemia without proper prior topical treatment.

Health professionals, especially the nursing staff, are world-renowned for their heroism, their struggle and their self-sacrifice in caring for others. However, it is fundamental that self-care prevails at this time of pandemic, because it is necessary that professionals have their health preserved in order to collaborate with effective care for society.

\section{ACKNOWLEDGMENTS}

The authors thank the collaboration of the Grupo de Pesquisa em Estomaterapia: estomas, feridas agudas e crônicas e incontinências urinária e anal, da Escola de Enfermagem da Universidade de São Paulo (GPET-EEUSP, Enterostomal Research Group: Stomas, acute and chronic wounds and urinary and anal incontinence, of the Nursing School of the University of São Paulo).

\section{REFERENCES}

1. World Health Organization (WHO). Rational use of personal protective equipment for coronavirus disease 2019 (COVID-19): Interim guidance. Genebra: WHO; 2020. [cited in 21 mar 2020]. Available at: https://apps.who.int/iris/bitstream/handle/10665/331215/ WHO-2019-nCov-IPCPPE_use-2020.1-eng.pdf

2. Monteiro N, Aquino V, Pacheco S, Scheneiders L. Saúde anuncia orientações para evitar a disseminação do coronavírus. Brasil: Ministério da Saúde; 2020. [cited in 21 mar 2020]. Available at: https://www.saude.gov.br/noticias/agencia-saude/46540-saudeanuncia-orientacoes-para-evitar-a-disseminacao-do-coronavirus

3. Associação de Medicina Intensiva Brasileira (AMIB). Na UTI, a segurança da equipe é fundamental! São Paulo: AMIB; 2020. [Cited in 21 mar 2020]. Available at: https://www.amib.org.br/fileadmin/user_upload/amib/2020/marco/07/COVID-19_seguranca_ equipev14032020_18h16.pdf

4. National Pressure Ulcer Advisory Panel (NPUAP). National Pressure Ulcer Advisory Panel (NPUAP) announces a change in terminology from pressure ulcer to pressure injury and updates the stages of pressure injury. Washington: Wound Source; 2016. [cited in 21 mar 2020]. Available at: https://www.woundsource.com/blog/national-pressure-ulcer-advisory-panel-npuap-announceschange-in-terminology-pressure-ulcer

5. Caliri MHL, Santos VLCG, Mandelbaum MHS, Costa IG. Classificação das Lesões por pressão - Consenso NPUAP 2016 - Adaptada Culturalmente para o Brasil. São Paulo: SOBEST/SOBENDE; 2016. [cited in 21 mar 2020]. Available at: http://www.sobest.org.br/ textod/35

6. Mills J. Medics left with sore marks all over their skin from coronavirus face masks. Londres: Metro; 2020. [cited in 21 mar 2020]. Available at: https://metro.co.uk/2020/02/05/medics-left-sore-marks-skin-coronavirus-face-masks-12188952/

7. Utaraitè N. Chinese nurses share pictures of how their faces look after countless hours fighting the coronavirus. Bored Panda. [cited in 26 mar 2020]. Available at: https://www.boredpanda.com/chinese-nurses-face-masks-corona-virus/?utm_source=google\&utm_ medium=organic\&utm_campaign=organic

8. Gefen A, Alves P, Ciprandi G, Coyer F, Milne CT, Ousey K, et al. Device-related pressure ulcers: SECURE prevention. J Wound Care. 2020;29(Sup2a):S1-52. https://doi.org/10.12968/jowc.2020.29.Sup2a.S1

9. European Pressure Ulcer Advisory Panel; National Pressure Injury Advisory Panel; Pan Pacific Pressure Injury Alliance. Prevention and Treatment of Pressure Ulcers/Injuries: Clinical Practice Guideline - The International Guideline. EPUAP/NPIAP/PPPIA. 2019. 